\title{
Graham Connah: The So Pots of Central Africa: Memories of the Past
}

\author{
BAR Publishing, Oxford, 2019, 79 pp., ISBN 978-1407-31688-8
}

\author{
Carlos Magnavita
}

Published online: 8 April 2021

(C) The Author(s) 2021

This is the latest of several highly influential volumes written by Graham Connah since 1975, most of which were dedicated to the archaeology of Africa (Connah 2012). The book reports on a remarkable but still poorly researched category of artifact typical of the later cultural sequence in the Lake Chad region: the so-called "So pots." These are enormous ceramic containers named after, and attributed to, a pre-Islamic people variously called "Sao," "Sau," or "So," whom local legends recognize as an extinct race of giants. As Connah reveals, the "So pots" are most notable for being unearthed, reused, and curated during the past century by the Makari/Kotoko, inhabitants of the firki clay plains to the south of the lake, who use them for dying, grain and water storage, and, perhaps, as beer containers (p. 7, 23, 31-33). Since the early-twentieth century, these vessels have become famous even beyond the region where they were once produced and used.

The author outlines two motivations for writing a book exclusively about these massive pots (p. xvi). First, there are reasonable concerns about their survival, particularly as regional terrorist actions have become a pervasive threat to local peoples and culture since 2009. An example comes from the attack by Boko Haram extremists on the town of Dikwa in September 2014. On that occasion, the local museum had their archaeological and ethnographic collections burned in

C. Magnavita $(\square)$

Frobenius Institute at Goethe University, Frankfurt, Germany e-mail: c.magnavita@em.uni-frankfurt.de public to intimidate the indigenous population (pers. comm. February 2019, Daniel Ishaya, Dikwa site manager). Second, the time seemed right to provide a synthesis of information on these artifacts and their contexts, while also making available a significant set of photographs recording "So pots" still standing in Makari/Kotoko villages in the 1960s and 1990s.

Guided by some exploratory questions about the pots, the book includes several short chapters that address the circumstances of their discovery and popular interest in the twentieth century, as well as their techniques of production, primary and secondary uses, and chronology. As Connah explains in Chapter 3, the initial knowledge of the "So pots" came from the first surveys and descriptions of Lake Chad and its inhabitants by French, British, and German colonial officials and travelers in the early-twentieth century. In the 1950s, those early accounts sparked the late colonial interest in "So pots," particularly within the scope of nation building and the process of constructing a Nigerian national identity. It is in this context that, as Connah states in Chapter 2, the first well-preserved specimens of "So pots" probably left their homeland in the firki clay plains, being conveyed to central Nigeria to be exhibited in the recently built Jos Museum. Despite the public attention received from the 1950s onward, the "So pots" never became central subjects of archaeological inquiry (Chapter 4), so that questions regarding their past manufacture and dating remain poorly understood. In Chapter 5, Connah attempts to fill part of that gap by discussing the possible methods for producing these enormous containers, the kind of tempers used, and the 
potters' gender. For this, he draws on the results of previous pottery research in Africa and elsewhere but provides little conclusive information beyond the notion that the "So potters" were possibly women. However, the most interesting point in Chapter 5 is the observation that carved rouletting was the main technique for decorating "So pots." This is relevant because carved roulettes have been demonstrated to be a late phenomenon in the southern Chad Basin (ca. $700 \mathrm{AD}$ onwards), thus providing, along with stratigraphic observations, first clues for dating those pots.

While there have been no detailed analyses of these artifacts, early archaeological excavations in the Republic of Chad furnished positive evidence for the primary use of "So pots" as burial containers. Chapter 6 discusses the pros and cons of this and other archaeological data from Cameroon and Nigeria. However, Connah initially hesitates to accept the "So pots" as burial vessels, raising the possibility in Chapter 7 that they might have been ancient (sorghum) beer fermenters as he proposed 40 years ago (Connah 1981, p. 191). Despite those conflicting interpretations, Connah concludes later in the book that "The overwhelming evidence in Chad, Cameroon and Nigeria is that they were burial pots..." (p. 32), thus acknowledging this interpretation as the most plausible. Nonetheless, he tacitly assumes that follow-up research may be able to settle the question of their function and other problems surrounding the pots (pp. 26-27).

Besides the riddle of their primary use, a question that remains poorly answered is the dating of the "So pots." In Chapter 8, Connah considers the results of several excavations in Nigeria (e.g., Daima, Mege, and Ndufu) and other data to deduce that these containers must be relatively late in date. He proposes "a terminal date...in the sixteenth or seventeenth century" (p. 29) but remains silent on the initial period of production and use of the pots. Previously, however, he has suggested a connection between the appearance of these large vessels and the intensification of sorghum cultivation in the firki clay plains from AD 800 onwards (Connah 1981, p. 189-191). It is conceivable that his silence regarding this latter point reflects some doubts about that early assumption, possibly because of the intricate problems of association between stratigraphy, artifacts, and radiocarbon dates both in Daima and other sites of the region.
The fact is, however, that he, unfortunately, leaves the reader in the dark about his current thoughts on the issue.

Unlike the challenging topics of function and chronology, Connah is relatively confident about the cultural significance and symbolism behind the "So pots" that were unearthed and reused by the Makari/Kotoko. In Chapter 9, he concludes that these people not only valued the pots because they were useful but also "because they were old and belonged to the past, as well as for symbolic reasons" (p. 31). As Connah maintains in the concluding Chapter 10, "the pots provided a tangible means of connection with those people [that is the Makari/Kotoko ancestors or forebears] whoever they had been" (p. 34). In this respect, the meanings of the "So pots" have evolved over the centuries. As resilient objects of the past, they survived the ravages of time after fulfilling primary and secondary practical functions; as curated artifacts, they have come to serve as mnemonic devices for remembering that past.

Whether intentionally or not, this book widens the mnemonic function ascribed to the "So pots." Its strength is that it prompts one to think about these unique African artifacts and especially about how they might have been originally used and when they might have been first produced. These unanswered questions might eventually be addressed by new techniques, such as employing residue analysis and obtaining thermoluminescence dates from stratified "So potsherds." These are two of the numerous research topics to be tackled by future generations of archaeologists working in the Lake Chad region.

Funding Open Access funding enabled and organized by Projekt DEAL.

Open Access This article is licensed under a Creative Commons Attribution 4.0 International License, which permits use, sharing, adaptation, distribution and reproduction in any medium or format, as long as you give appropriate credit to the original author(s) and the source, provide a link to the Creative Commons licence, and indicate if changes were made. The images or other third party material in this article are included in the article's Creative Commons licence, unless indicated otherwise in a credit line to the material. If material is not included in the article's Creative Commons licence and your intended use is not permitted by statutory regulation or exceeds the permitted use, you will need to obtain permission directly from the copyright holder. To view a copy of this licence, visit http://creativecommons.org/licenses/by/4.0/. 


\section{References}

Connah, G. (1981). Three thousand years in Africa: Man and his environment in the Lake Chad region of Nigeria. Cambridge: Cambridge University Press.
Connah, G. (2012). Bibliography: Graham Edward Connah. Azania: Archaeological Research in Africa, 47(3), 365-374.

Publisher's Note Springer Nature remains neutral with regard to jurisdictional claims in published maps and institutional affiliations. 